\title{
A Preliminary Study: Marine Biogeography of Nautilus in the Bangka Belitung Seas, Indonesia
}

\author{
Siti Aisyah1*, Josaphat Tetuko Sri Sumantyo², Aditya Pamungkas³, M Rizza Muftiadi¹, \\ Muh Yusuf4
}

\author{
${ }^{1}$ Aquatic Resource Management Department, Faculty of Agriculture Fisheries and Biology, \\ Universitas Bangka Belitung \\ Jl. Kampus Terpadu Universitas Bangka Belitung, Kepulauan Bangka Belitung 33172, Indonesia \\ 2Josaphat Microwave Remote Sensing Laboratory, Center for Environmental Remote Sensing, Chiba University \\ 1-33, Yayoi-Cho, Inage-Ku, Chiba-Shi 263-8522, Japan \\ ${ }^{3}$ Marine Science Department, Faculty of Agriculture Fisheries and Biology, Universitas Bangka Belitung \\ Jl. Kampus Terpadu Universitas Bangka Belitung, Kepulauan Bangka Belitung 33172, Indonesia \\ ${ }^{4}$ Oceanography Department, Faculty of Fisheries and Marine Science, Universitas Diponegoro \\ Jl. Prof. Soedarto, S.H. Tembalang, Semarang 50275, Jawa Tengah, Indonesia. \\ Email: sitiaisyahsa057@gmail.com
}

\begin{abstract}
Nautilus is the only surviving genus whose members were numerous and widely dispersed in the oceans throughout the Jurassic and Miocene times. It represents the only living member from the Family Nautilidae and is often considered as a living fossil. Nautilus is found with high biodiversity in Ambon, Indonesia, and were in special cases even found in Bangka Belitung, far from their original habitat. This study aimed to understand the historical component of the habitat and distribution of Nautilus in Bangka Belitung and to determine the depth, temperature, current, and environmental heterogeneity relate to Nautilus. Nautilus samples were found in Bangka Belitung Seas nearby a crack region at 50-75 m deep while the optimal depth of the Nautilus was 150-300 m, depending on the local area. The locations in the Bangka Belitung Seas where Nautilus found have sea surface temperatures between $30-31^{\circ} \mathrm{C}$ and $27-28^{\circ} \mathrm{C}$ during the East Monsoon and the West Monsoon respectivelly. The implications of temperature as a limiting factor are fairly significant, as it restricts the upper limit of the living habitat to predictable depths, which vary both geographically and seasonally during the West Monsoon when surface temperatures approach habitable levels. Sea currents at the Bangka Belitung Seas move at 0-0.6 m.s ${ }^{-1}$ during the East Monsoon and speed up near the North Natuna Sea. During the West Monsoon, currents predominantly flow from the Natuna Sea to the Java Sea at 0-0.5 m.s ${ }^{-1}$. Large-scale deep-water currents and the effects of smaller currents on scent dispersal influence the directional movements of Nautilus.
\end{abstract}

Keywords: nautilus, marine biogeography, Bangka Belitung, living fossil, environmental

\section{Introduction}

The genus Nautilus is known to be represented by at least six extant species that inhabit a well circumscribed large area in the Southwertern Pasific Ocean, The Philippines, Indonesia and Australia. Having survived relatively unchanged for hundreds of millions of years, Nautilus represents the only living members of Family Nautilidae and are often considered as living fossils (Saunders and Landman, 2010). The Quaternary period represents the most recent moments of Earth's history and despite its current relatively brief duration, knowledge of its faunas is highly important as they are close ancestors of modern ones. When some of the main concerns about animal life are diversity, biological invasions, and range modifications caused by global change, an analysis of the near past can show diverse geological and biological clues for understanding and managing present ecosystems (Martinez et al., 2003). The genus Nautilus is known to be represented by at least six extant species that inhabit in a well-circumscribed extensive area in the southwestern Pacific Ocean, the Philippines, Indonesia, and the tropical seas of Australia (Saunders and Landman, 2010).

Miller (1949) was the first to recognize that the evolution of Nautilida surged ahead in the Late Cretaceous and Early Tertiary periods and across the Cretaceous-Tertiary boundary, at which time the Ammonoidea became extinct. However, it is by no means close to natural extinction. On the contrary, Nautilus is a viable genus on the threshold of a new period of evolutionary radiation that, given favorable climatic and other environmental conditions, may unfold during the next few million years. The first specialist to publish an article on a Nautilida fossil included Nautilus was Shimansky (1957) whose studied 
Nautilus praepompilius from the Eocene period of Russia. Squires (1988) described Eocene specimens and placed them in the Family Nautilida. Saunders et al. (1989) followed Shimansky (1957) and went into further detail on similar fossils.

Biogeography is the study of the distribution of organisms and of principles that govern it. This discipline plays a critical role in understanding marine biota evolution and adaptation. The field of biogeography is rich in studies of small groups of better-known species at local to regional scales (Briggs and Bowen, 2012), but has relatively few examples of generalized studies (Kreft and Jetz, 2010). There are three models in biogeography for studying origins within marine biodiversity of Pacific and Indian Ocean faunas, namely the 1) center of origin, 2) center of accumulation, and 3) center of overlap. The center of origin model is the most supported, premising a flow of species from highdiversity centers enhancing species abundance in outlying communities (Briggs and Bowen, 2013). Previous research has shown that some migration may take place inward and toward the diversity center (Saunders and Landman, 2010). Marine biogeography is necessary for the planning of conservation strategies and management interventions, especially for Nautilidae.

Marine biogeography of Nautilus is highly complex and explaining the distribution patterns may require the synthesis of current ecological and biogeographical theories. One area where Nautilus has been found is Ambon, Indonesia. Nautilus inhabit deep continental shelves with the optimal range seeming to be $150-300 \mathrm{~m}$. The worldwide biogeographic distribution of Nautilus is restricted to the Indo-Pacific region on steep coral reef drop-offs and at depths of 0-700 m (Dunstan and Ward, 2010). In an unexpected occurrence, Nautilus was found in Bangka Belitung, far from their original habitat, where the maximum water depth is $50-75$ $\mathrm{m}$. This study aimed to clarify the historical component of the habitat and distribution of Nautilus in Bangka Belitung and to determine how depth, temperature, currents, and environmental heterogeneity relate to Nautilus.

\section{Materials and Methods}

\section{Data collections}

The samples were collected by local fisherman around 2018 - 2020 which catching at the Nasik Strait and Seliu Island, Belitung Regency, Bangka Belitung Islands, Indonesia. Purposive sampling was done at the locations where drifting Nautilus shells were sighted.

\section{Bathymetry data}

Bathymetry which describes the depth profile of the ocean has been use for predict the habitat of Nautilus. Bathymetry data based on the General Bathymetry Chart of the Ocean (GEBCO) and obtained from the GEBCO website at https://download.gebco.net/. The resolution was set to $15 "$.

\section{Currents and sea surface temperatures}

To analyze the relation between Nautilus distribution and oceanographic conditions, the currents and sea surface temperature (SST) profile of the study area was studied. The currents and SST profile were obtained from the InaROMS RCP45 model made by the Indonesian Geospatial Information Agency and is accessible at http://tides.big.go.id:8080/las/Ul.vm. The profile comprises a reanalysis of model results and field data, specifically from the territorial waters of Indonesia at a $5 \mathrm{~km}$ resolution. The East Monsoon period between July 1-31, 2019 and the West Monsoon period between January 1-31, 2020 of the currents and SST profile were investigated.

\section{Result and Discussion}

\section{Center of origin and dispersal}

Nautiluses are primarily mobile benthic bottom dwellers associated with coral reefs. They are found at depths ranging from the surface until $500 \mathrm{~m}$, but their optimal range seems to be from 150-300 m (Jereb and Roper, 2005). Previous studies investigated Nautilida both in the wild and in captivity from a wide range of populations, including from the Philippines, Palau, Indonesia, Papua New Guinea, Fiji, and Australia, to provide data on distribution, habitat, growth, time to maturity, and lifespan (Collins and Ward, 2010; Landman and Cochran, 2010). (a) Nautilus macromphalus, Sowerby (1849) inhabits continental shelves and slope waters associated with coral reefs, ranging from the surface to roughly $500 \mathrm{~m}$ deep. They are currently only known to be found in northeastern Australia and the Loyalty Islands province in New Caledonia. Drift shells have been recorded as far south as Lizard Island, Queensland, Australia (Jereb and Roper, 2005). (b) Nautilus pompilius Linnaeus (1758) is the most widely distributed and best-known Nautilus species. It inhabits deeper continental shelves around coral reefs and found at surface levels down to $750 \mathrm{~m}$ deep. They are geographically distributed around the Indo-West Pacific, ranging from the Andaman Islands to Ambon in Indonesia, the Philippines, New Guinea, and Fiji, and northeastern and northwestern Australia (Jereb and Roper, 2005). (c) Nautilus belauensis, Saunders (1981): This species of Nautilus was 
named for their characteristically large forms and are found in Palau (Belau) and the western Caroline Islands (Saunders, 1981a). Nautilus belauensis is known only from its typical locality, Palau, although there have been no attempts to establish whether its range extends to any of the adjacent Caroline Islands. Some $N$. belauensis specimens were caught at depths of 100-400 m (Saunders and Landman, 2010). (d) Nautilus repertus, Iredale (1944): The specimens described by Iredale (1944) were found off the western coast of Australia at Pelsaert Island, Houtman Abrolhos, and Rottnest Island. A specimen with soft parts was found in Foul Bay in South Australia, directly off the coast of Yorke Peninsula (Riddle, 1920). Most recently, 14 shells of live-caught specimens were obtained by deep-water shrimp bottom-trawls, operating approximately $200 \mathrm{~km}$ off Broome, Western Australia, at a depth of 380-450 m (Saunders and Landman, 2010). (e) Nautilus stenomphalus, Sowerby (1849): Nautilus stenomphalus has only been found in the Great Barrier Reef, Queensland, Australia, whence most drift shells ascribed to this species are also derived, suggesting that its range may be limited to that region (Saunders and Landman, 2010). (f) Allonautilus scrobiculatus, Lightfoot (1786): Allonautilus scrobiculatus is found in the tropical West Pacific, specifically in the Bismarck Archipelago and Milne Bay of Manus, Papua New Guinea. Drift shells have been found as far south as the Solomon Islands. (g) Allonautilus perforatus, Conrad (1847): Allonautilus perforatus has only been found in Bali, Indonesia.

Surprisingly, some Nautilus were found in Bangka Belitung (Figure 1.), far from genus Nautilus' known habitats. Several Nautilus samples from Bangka Belitung were found near a crack which is characterized by an area deeper than is surrounding (>50 m) (Figure 2.).

\section{Oceanographic conditions of Bangka Belitung}

Oceanographic conditions are an important supporting aspect of the Nautilus distribution analysis, especially for the interconnectivity of Nautilus from different regions. Other aspects are bathymetry, currents, and sea surface temperatures. In Bangka Belitung itself, the ocean floor is fairly shallow at around 0-75 m due to Bangka Belitung being on the Asian continental plate, similar to
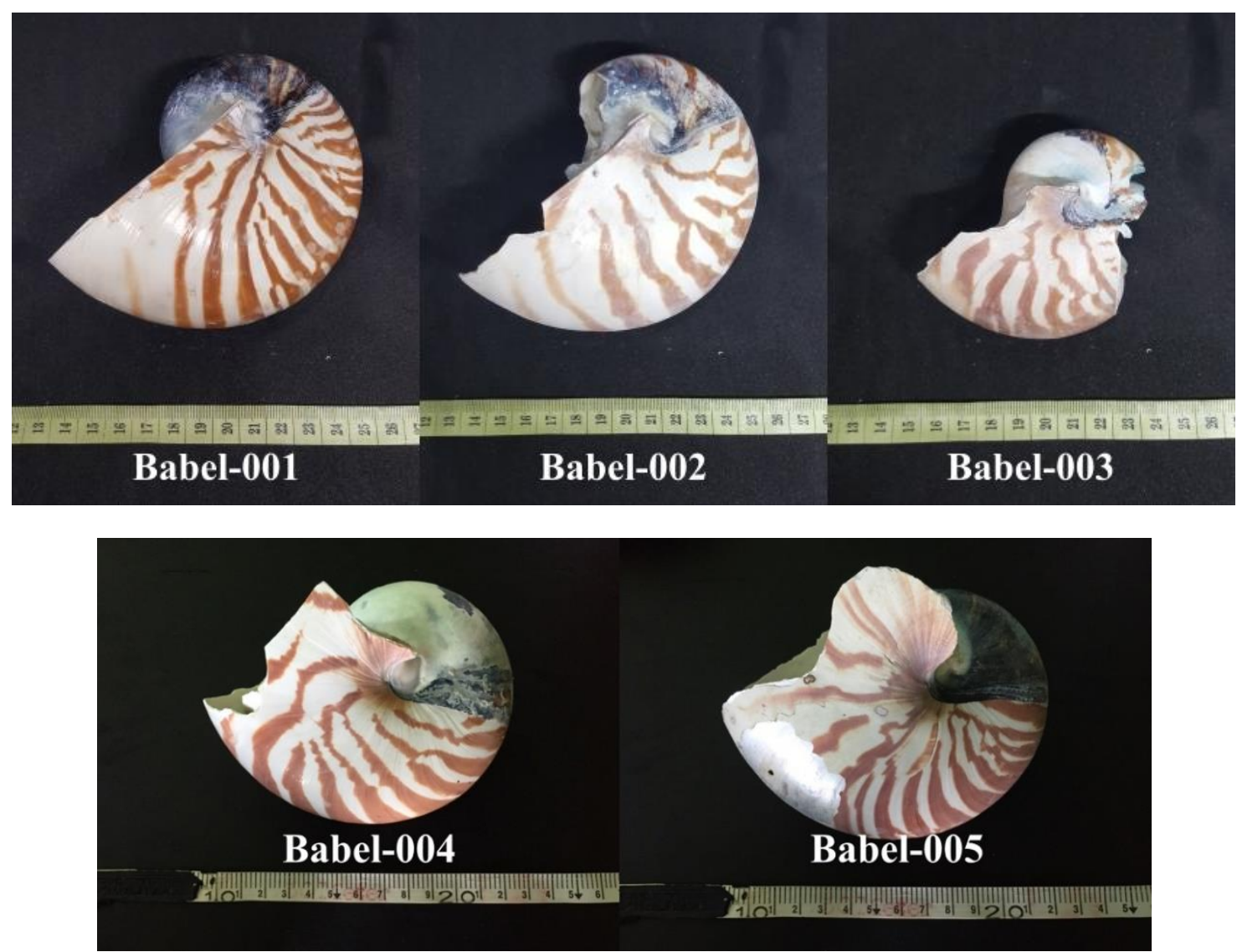

Figure 1. Data collection of Nautilus from Bangka Belitung. (length of sample: Babel-001: $11.4 \mathrm{~cm}$; Babel-002: $12.2 \mathrm{~cm}$; Babel003: $8.7 \mathrm{~cm}$; Babel-004: $12 \mathrm{~cm}$; Babel-005: $11.8 \mathrm{~cm}$ ) 
Singapore's, Malaysia's, and Thailand's shallow waters. At Gaspar Strait, situated between Bangka Island and Belitung Island (Figure 2.), there is a narrow crack extending from the south (Sunda Strait) to northwest (Singapore, Melaka Strait, Thailand) (Figure 2.) which is deeper than its surrounding and reaches $75 \mathrm{~m}$.

Five nautiluses were found at Bangka Belitung near the crack region (Figure 2.), but not in other locations. This showed that the Nautilus habitat in Bangka Belitung waters was primarily in the narrowdeep crack. According to Jereb and Roper (2005) and Saunders and Landman (2010), the optimal depth of Nautilus habitats is around $150-300 \mathrm{~m}$ and no deeper than $800 \mathrm{~m}$, determined by shell implosion and chamber flooding. Factors controlling the habitat's upper limits include predators and temperature. Temperatures exceeding $25^{\circ} \mathrm{C}$ may be lethal to Nautilus. However, this limitation does not prevent them from moving into warm, shallow water for brief periods as $N$. business has been found in water approaching $28^{\circ} \mathrm{C}$, but such incursions are probably of short duration $(<10 \mathrm{~h})$.

Western Indonesia (including the Bangka Belitung Seas) is strongly influenced by monsoon winds. The monsoons comprise two phases, namely the East Monsoon in June, July, and August (JJA) and the West Monsoon in December, January, and February (DJF) (Wei et al., 2016). The Sea Surface Temperature (SST) analysis of the Bangka Belitung Seas shows that this study's nautiluses were found where surface temperatures range between $30-31^{\circ} \mathrm{C}$ during the East Monsoon and between $27-28^{\circ} \mathrm{C}$ during the West Monsoon. Optimal temperatures for Nautilus at $<100 \mathrm{~m}$ deep range from $23-25^{\circ} \mathrm{C}$ and $15-18^{\circ} \mathrm{C}$ at $150-180 \mathrm{~m}$ deep (Saunders and Landman, 2010). Their minimum water depth is constrained by water temperatures above $28^{\circ} \mathrm{C}$. As most shallow waters across the range of the Nautilus habitat are warmer than this, these high surface water temperatures and visual predators make dispersal in surface and near-surface waters rare (Carlson, 2010; Williams et al., 2012). The implications of temperature as a limiting factor are fairly significant. It restricts the upper limit of habitats and long-term migration to predictable depths, which vary both geographically and seasonally. Thus, extensive movement across shallow-water platforms, such as the Palau Archipelago, is not possible, but shallow-water occurrences of Nautilus, as reported in New Caledonia and the Loyalty Islands, may be common during the winter months, when

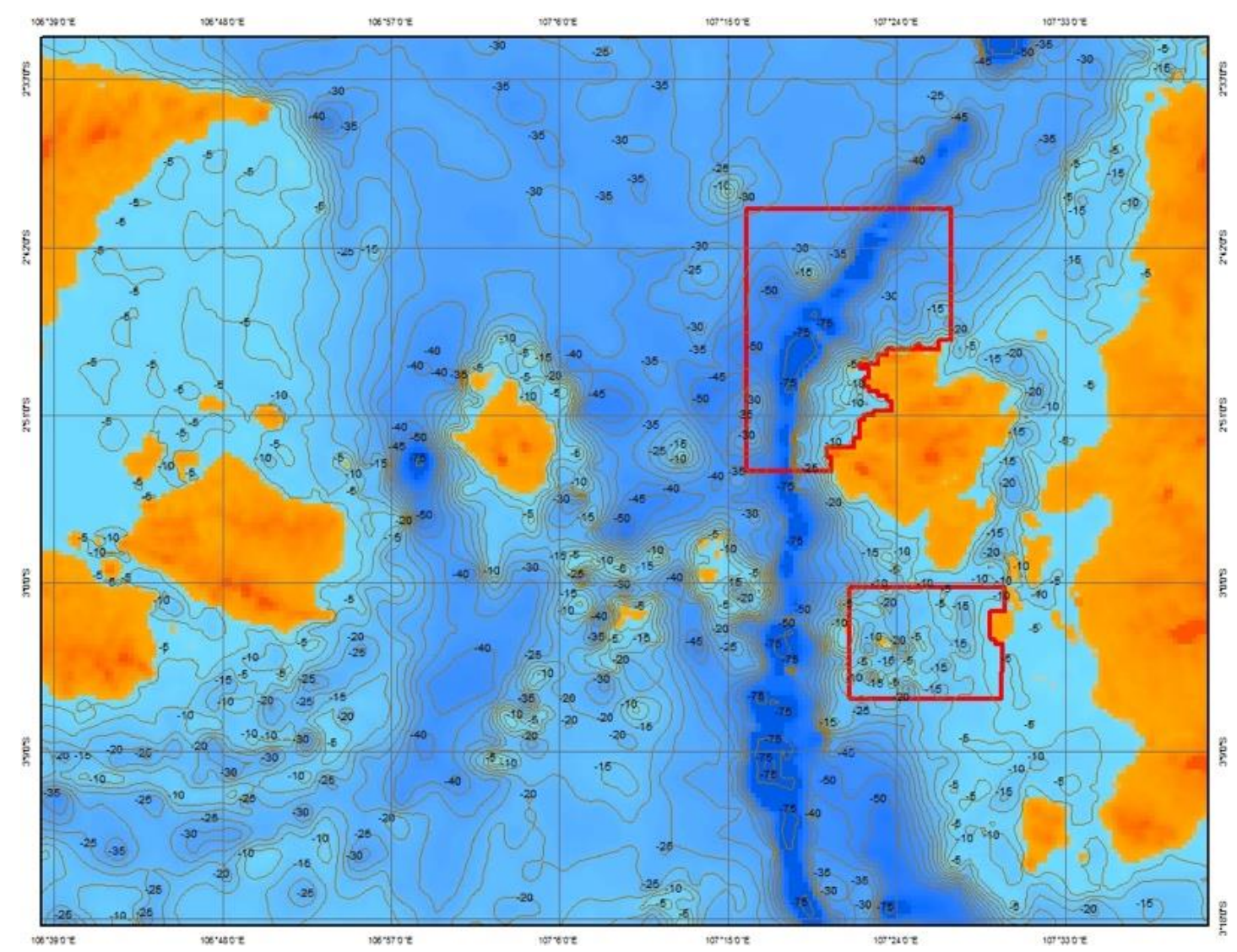

Figure 2. Bathymetry and spatial distribution of Nautilus in Bangka Belitung (Source: GEBCO https://download.gebco.net/ and field sampling data). The red boxes show the areas were Nautilus found 
surface temperatures approach habitable levels (Ward and Martin, 1980). Unclear is why Nautilus occurrences are not more common in regions where optimal temperatures are consistently encountered at shallower depths. This may be related to biological factors, as mentioned by Ward et al. (2016), Nautilus habitats are normally close to rich sources of tropical vegetation that bring copious amounts of carbon into the fore-reef slope muds, making these areas rich in nutrients and life.

Nautilus is irregular and unpredictable in their area of occupancy and their distribution in areas where they are known to occur is patchy. Nautiluses

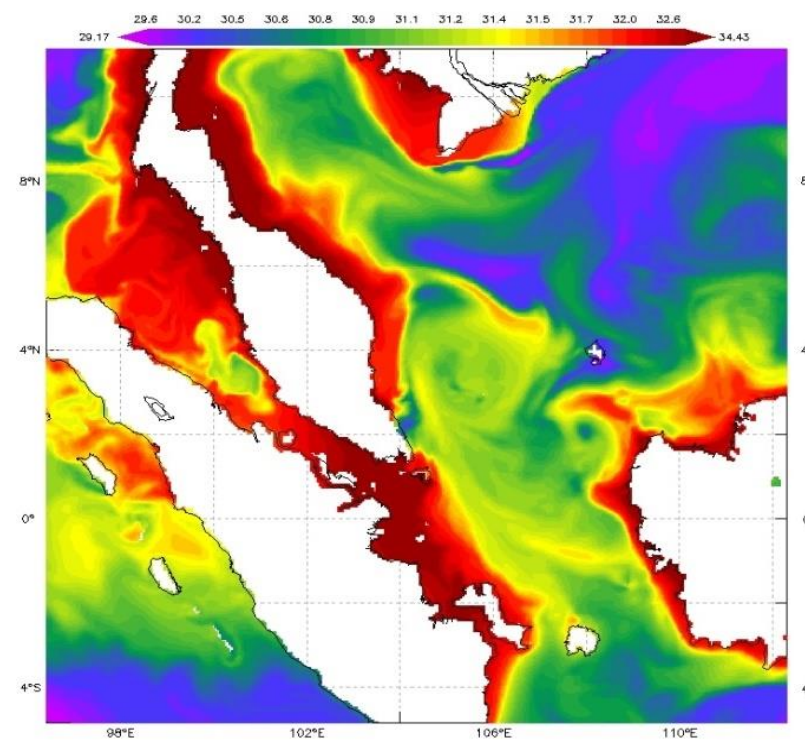

have physiological constraints that limit their vertical and horizontal distribution to geographicallyseparated areas of suitable habitat (Barord et al., 2014). In areas where water temperatures drop seasonally, chambered nautiluses will range into much shallower water nocturnally.

Winds blow from Asia to Australia during the East Monsoon, and vice versa during the West Monsoon. These winds greatly influence the current patterns of the Bangka Belitung Seas (Pamungkas, 2018) because geographically the Bangka Belitung Seas are between two oceans (Natuna and Java Seas) and between two large islands (Sumatera and

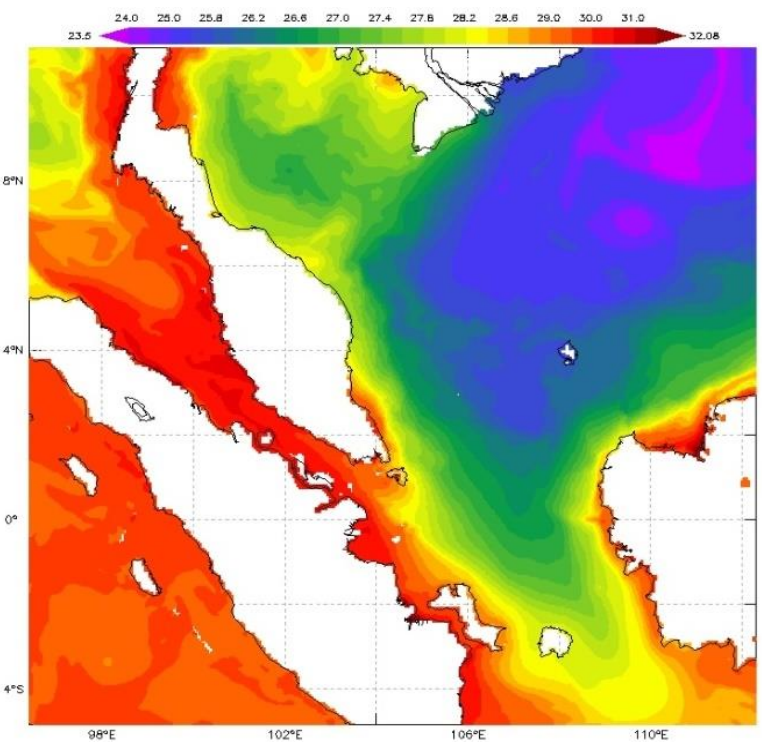

Figure 3. Sea Surface Temperatures (SST) of Bangka Belitung and surroundings during the East Monsoon (left) and the West Monsoon (right) (Source: Ina ROMS rcp45, http://tides.big.go.id:8080/las/UI.vm).
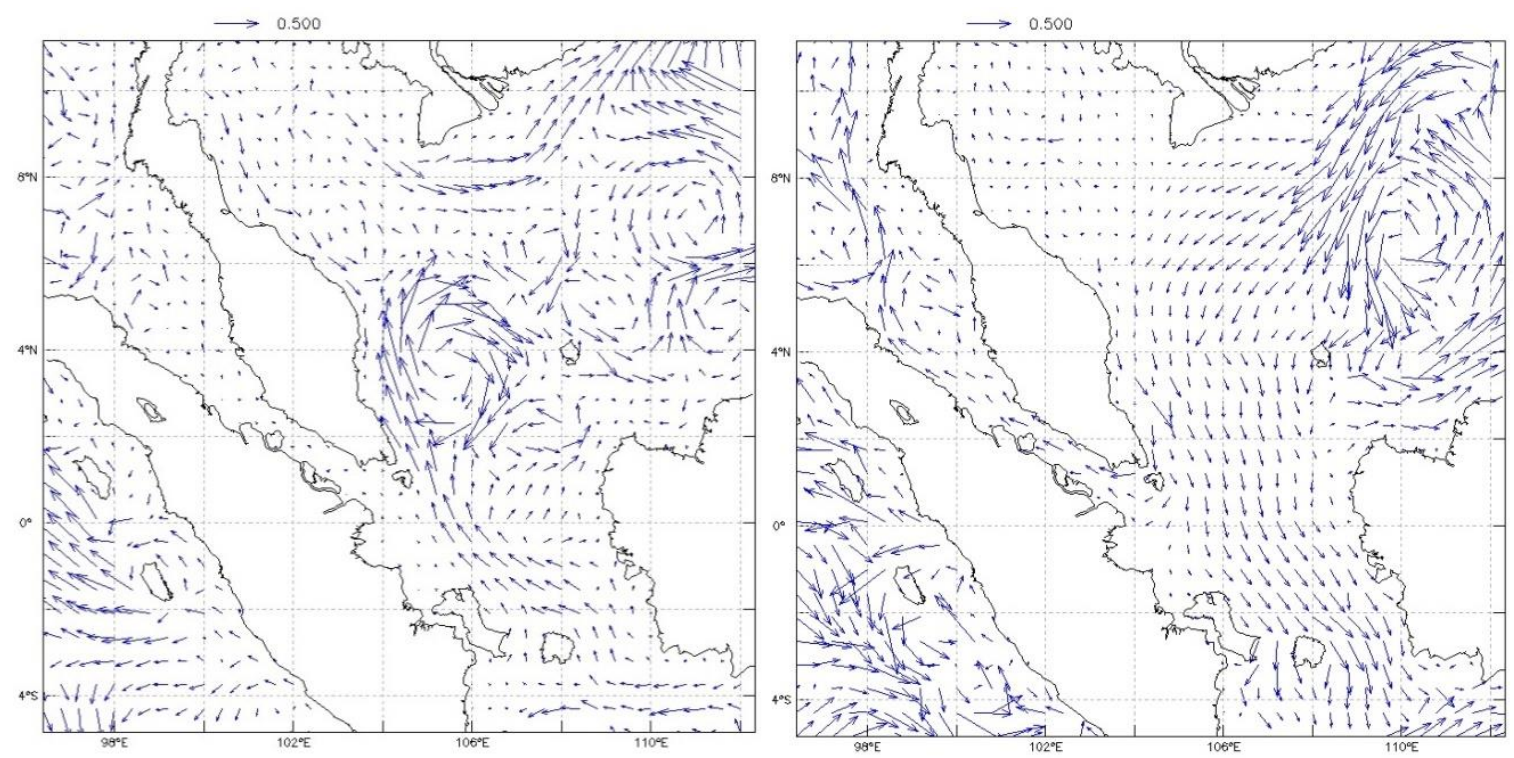

Figure 4. A current profile of the Bangka Belitung Seas and surroundings during the East Monsoon (left) and the West Monsoon (right) (Source: Ina ROMS rcp45, http://tides.big.go.id:8080/las/UI.vm). 
Kalimantan Islands) (Ambalika et al., 2019). Currents during the East Monsoon follow the direction of the wind and predominantly flow from the south (the Java Seas) to the north (the Natuna Sea) (Figure 4.). During the East Monsoon, current speeds are around 0 $0.6 \mathrm{~m} . \mathrm{s}^{-1}$ and are amplified as they approach the North Natuna Sea (Eastern Malaysia). During the West Monsoon, as the winds blow from north to south, currents flow from the Natuna Sea to the Java Sea (Figure 4) at 0-0.5 m.s ${ }^{-1}$. Currents tend to move faster in the South China Sea and slow down as they approach the Bangka Belitung Seas. Another current flows through the Malaka Strait during both the East and West Monsoon connects the Bangka Belitung Seas with the West Thailand Sea. The directions of movement of Nautilus may be influenced by largescale deep-water currents, they may be related to the effects of smaller currents on scent dispersal, or they may be random (Saunders and Landman, 2010).
The Nautilus found in the Bangka Belitung Seas around the crack region (Figure 2) is expected to be related to Nautilus from the Thailand Sea (Figure 5.) because the crack with a depth of up to $75 \mathrm{~m}$, where drifted shells of Nautilus were found, connects both seas (Figure 6.). The Nautilus drift shells found in the Thailand Seas are from the same species as those found in the Bangka Belitung Seas, namely Nautilus pompilius (Saunders and Landman, 2010). Ward et al. (2016) explained that the Nautilus habitat is partly characterized by deep sloping sandy bottoms with little to no structure, and partly by sharp, steep reef slopes with varying depth changes. Nautilus depth movement was more gradual and consistent on sandy sea beds and more varied when migrating through rocky sea beds and reef walls. Therefore, the environmental structure of Nautilus habitats may be useful for determining how nautiluses migrate.

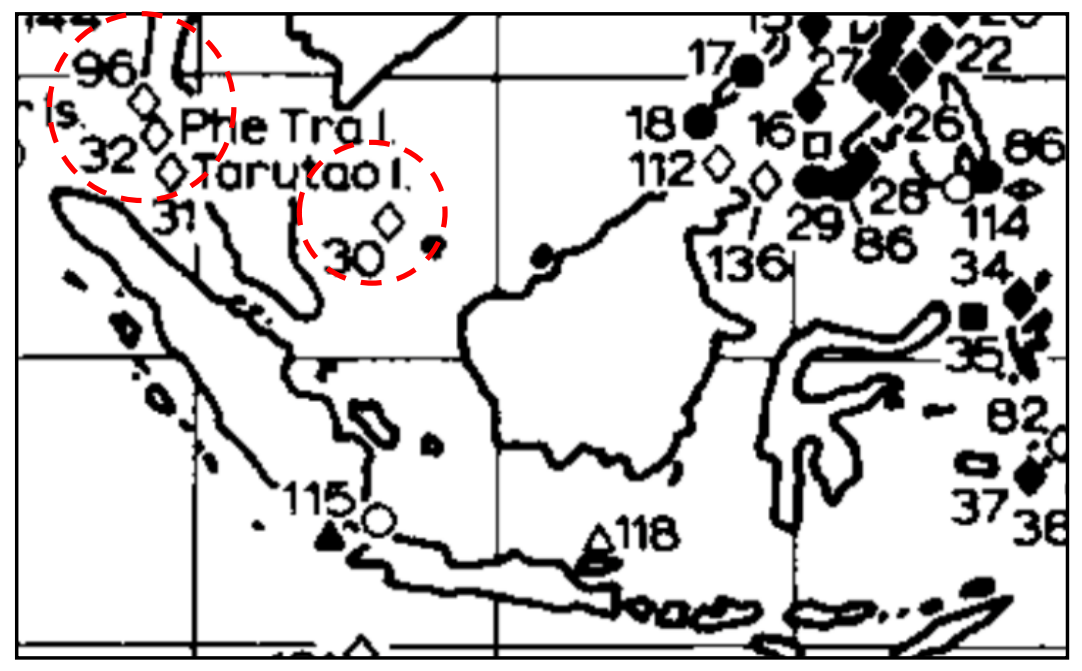

Figure 5. Recorded distribution of living Nautilus (black points) and Nautilus drift shells (white point) (Adaptation: Saunders and Landman, 2010). The striped red circles are recorded locations of Nautilus in the Thailand Sea.
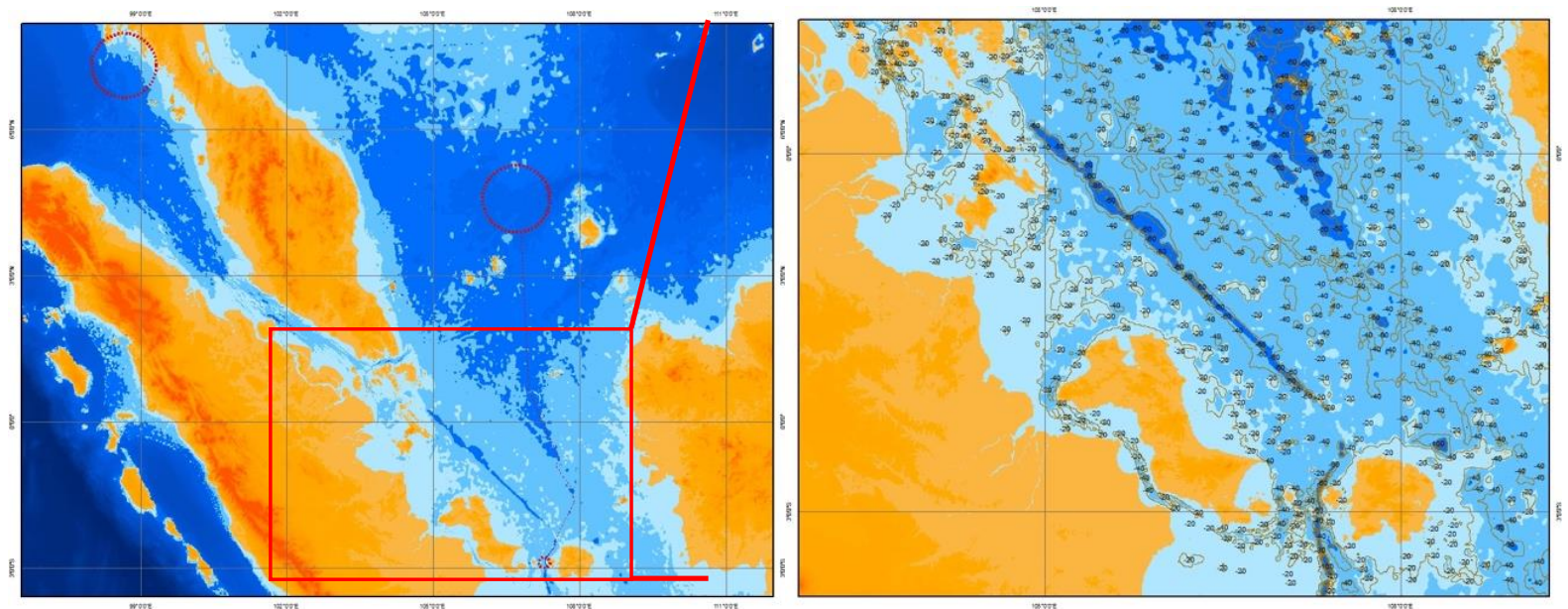

Figure 6. Bathymetry map of the Bangka Belitung Seas and the West Thailand Sea (Source: GEBCO https://download.gebco.net/). 
The depth, currents, and SST analyses correlate with the discovery of Nautilus in the Bangka Belitung Seas. This becomes an important role to preserve Nautilus because all species are vulnerable to exploitation based both on intrinsic biological traits, including their limited biogeographic distribution and selected life history strategy, and extrinsic threats of being targeted, a largely unregulated harvest, and mortality or habitat degradation caused by other human activities such as destructive fishing practices and overfishing.

\section{Conclusions}

Nautilus shells were found in the crack region in the Bangka Belitung Seas at 50-70 m deep. The SST where Nautilus was found ranges between 30 $31^{\circ} \mathrm{C}$ during the East Monsoon and between 27$28^{\circ} \mathrm{C}$ during the West Monsoon. The speed of currents in the Bangka Belitung Seas during the West Monsoon is $0-0.6 \mathrm{~m} . \mathrm{s}^{-1}$ and is amplified near the North Natuna Sea. During the West Monsoon, currents of the Bangka Belitung Seas predominantly flow southward from the Natuna Sea to the Java Sea with speeds of $0-0.5 \mathrm{~m} \cdot \mathrm{s}^{-1}$. The directional movements of Nautilus may be influenced by largescale deep-water currents and the effects of smaller currents on scent dispersal. Because of its difference from other Nautilus habitats, it can be argued that the appearance of Nautilus in the Bangka Belitung Seas is somewhat of a rarity, despite the Bangka Belitung Seas being quite representative of Nautilus' habitats. In unscientific terms, nautiluses are rare.

\section{Acknowledgement}

The authors would like to thank the University of Bangka Belitung and the Josaphat Microwave Remote Sensing Laboratory, Center for Environmental Remote Sensing, Chiba University, Japan. Thanks also go out to Syahrin, student of Marine Science, University of Bangka Belitung, and to Rekky, graduate from Aquatic Resources Management, University of Bangka Belitung (Nasik Strait).

\section{References}

Ambalika, I., Akhrianti, I., Pamungkas, A., Nugraha, M.A. \& Umroh. 2019. Oceanography database development in Bangka Seas. Proc. Int. Conf. Mar. Archi., 167: 22-26. doi: 10.2991/icoma18.2019.6

Barord, G.J., Dooley, F., Dunstan, A., Ilano, A., Keister, K.N., Neumeister, H., Preuss, T., Schoepfer, S. \& Ward, P.D. 2014. Comparative population assesment of Nautilus sp. in the Philippines,
Australia, Fiji and American Samoa using baited remote underwater video system, PLOS ONE, 9(6): e100799. doi: 10.1371/journal.pone. 0100799

Briggs, J.C. \& Bowen, B.W. 2012. A realignment of marine biogeographic provinces with particular reference to fish distributions. J. Biogeogr., 39: 12-30. doi: 10.1111/j.1365-2699.2011.0261 3.x

Briggs, J.C. \& Bowen, B.W. 2013. Marine shelf habitat: biogeography and evolution. J. Biogeogr. 40(6): 1023-1035. doi: 10.1111/jbi.12082.

Carlson, B.A. 2010. Collection in aquarium maintenance of Nautilus. 563-578. In: Saunders, W.B. \& Landman, N.H. (eds.). Nautilus: the biology and paleobiology of a living fossil. Plenum Publishing Corporation, New York City. doi: 10.1007/978-90-481-3299-7_35

Collins, D. \& Ward, P. 2010. Adolescent growth and maturity in Nautilus. In Saunders WB, Landman NH. (Eds.). Nautilus: The biology and paleobiology of living fossil. Springer, Netherlands. doi: 10.1007/978-90-481-32997_29

Dunstan, A.J., Ward, P.D. \& Marshall, N.J. 2010. Vertical distribution and migration patterns of Nautilus pompilius. PLoS ONE, 6(2): e16311. doi: 10.1371/journal.pone.0016311.s001.

Jereb, P. \& Roper, C.F.E. 2005. Cephalopods of the world. An annotated and illustrated catalogue of cephalopod species known to date. Volume 1. Chambered nautiluses and sepioids (Nautilidae, Sepiidae, Sepiolidae, Sepiadariidae, Idiosepiidae and Spirulidae). FAO Species Catalogue for Fishery Purposes No 4 Vol 1, Rome.

Kreft, H. \& Jetz, W. 2010. A framework for delineating biogeographical regions based on species distribution. J. Biogeogr., 37: 2029-2053. doi: 10.1111/j.1365-2699.2010.023 75.x

Landman, N.H. \& Cochran, J.K. 2010. Growth and longevity of Nautilus. In; Saunders, W.B. \& Landman, N.H. (Eds.). Nautilus: The biology and paleobiology of living fossil. Springer, Netherlands. doi: 10.1007/978-90-481-3299-7_28

Martinez, S., Rio, C.J.D. \& Rojas, A. 2003. Biogeography of the quartenary molluscs of the Southwestern Atlantic Ocean. Springer, New York. 
Miller, A.K. 1949. The last surge of the nautiloid cephalopods. Evolution, 3: 231-238. doi: 10.1111/j.1558-5646.1949.tb00023.x

Pamungkas, A. 2018. Karakteristik parameter oseanografi (pasang-surut, arus, dan gelombang) di Perairan Utara dan Selatan Pulau Bangka. Buletin Oseanografi Marina, 7: 51-58. doi: 10.14710/buloma.v7i1.19042

Saunders, W.B., Bond, P.N., Hastie, L.C. \& Itano, D. 1989. On the distribution of Nautilus pompilius in the Samoas, Fiji, and Tonga. Nautilus, 103: 99-104.

Saunders, W.B. \& Landman, N.H. 2010. Nautilus: The biology and paleobiology of a living fossil. Springer, Netherlands. doi: 10.1007/978-90481-3299-7

Shimansky, V. 1957. New members of the order Nautilida in the USSR. Paleontologie Institut Materialy Osnovam Paleontologie 1: 35-41.

Squires, R. 1988. Cephalopods from the late Eocene Hoko River formation, northwestern
Washington. J. Paleontol., 62: 76-82. doi: 10. 1017/S0022336000018023

Ward, P.D. \& Martin, A.W. 1980. Depth distribution of Nautilus pompilius in Fiji and Nautilus macromphalus in New Caledonia. Veliger, 22: 259-264.

Ward, P., Dooley, F., \& Barord, G.J. 2016. Nautilus: biology, systematics, and paleobiology as viewed from 2015. Swiss, J. Paleontol., 135: 169-185. doi: 10.1007/s13358-016-0112-7

Wei, Z., Fang, G., Susanto, R.D., Adi, T.R., Fan, B., Setiawan, A., Li, S., Wang, Y. \& Gao, X. 2016. Tidal elevation, current, and energy flux in the area between the South China Sea and Java Sea. Ocean Sci., 12: 517-531.

Williams, R.C., Newman, S.J. \& Sinclair, W. 2012. DNA Barcoding in Nautilus pompilius (Molusca: Cephalopoda): evolutionary divergence of an ancient species in modern times. Invertebr. Syst. 26: 548-560. 